\title{
European welfare systems in official statistics: national and local levels
}

\begin{abstract}
In the last decades, European welfare systems have undergone continuous reforms in the light of financial pressures. Monitoring changes, requires considering several dimensions of welfare systems, such as the composition of risks and needs covered, the rules for accessing benefits or the type of social benefits delivered. Finally, it is relevant to take into account the geographical area where beneficiaries live, since in some countries local governments are assigned managing and, sometimes, legislative competencies on social protection areas. This paper aims at exploring official statistics on European welfare systems, focusing on social benefits. The objective is assessing if available statistics allow one to compare the level and kind of social benefits delivered across European countries both at national and sub-national levels. We focus on the Italian case to provide some examples.
\end{abstract}

Key words: Official statistics, social protection systems, local welfare

\section{Introduction}

In the last decades, European countries have undertaken innovation processes of their welfare systems, essentially through a reshaping of the role of public actors along with a reduction of financial resources.

Several aspects need to be considered to detect changes in welfare systems such as the composition of risks and needs covered, the rules for accessing benefits or the type of social benefits delivered. The level of decentralization of a welfare system represents a further key dimension to be considered since, in some countries, local governments are in charge of administrative and managerial responsibilities as well as of legislative power or political control. For example, the Italian Constitution (art. 117 as amended in 2001) provides a list of matters on which State and Regions (Nuts 2 level, Eurostat 2013b) have concurrent competencies. Among these, we find health protection, education, and complementary and supplementary 
social security. Furthermore, in several countries, municipalities play an important role in the field of social assistence (disability, old age, poverty etc.). As a result, the place of residence may represent a crucial dimension to understand the actual kind of social protection received by citizens.

The awareness of the importance of comprehensive, up to date, comparable and accessible data on social protection has impelled international official statistics to promote the stocktaking of existing social protection international data and indicators. Bonnet, F. and L. Tessier, 2013 describe the on-going process and presents a mapping of data and indicators. These pertain to most of the above-mentioned dimensions of welfare systems, however neither decentralization nor the need of territorial data are mentioned explicitly.

Here, we aim at stocktaking information given by European official statistics on social protection benefits both at national and local levels, and at investigating the real comparability in terms of social domains, classifications adopted, aggregation levels, timing and coverage. We discuss the coherence of data coming from different data sources pointing out common features and main differences. As an example, we use different sources to provide some empirical evidence on territorial disparities in Europe and, particularly, in Italy.

The paper is structured as follows. Section 2 presents the definition of social protection shared at international level and discusses the characteristics of social protection, which should be taken into account to properly monitor changes of welfare systems in time. Section 3 describes available European official statistics on social benefits whereas Section 4 points out their differences, similarities and main gaps. Some descriptive analyses are provided on territorial disparities in the provision of social protection benefits in Europe and in Italy. Section 5 illustrates conclusions.

\section{Social protection in official statistics: main concepts}

A universally accepted definition of the scope of social protection does not exist. Therefore, European official statisticians established a definition of social protection considering the needs of both producers and users of statistics. Such definition was proposed along with the development of Esspros (European system of integrated social protection statistics), a framework created in the late 1970's by Eurostat and European Union member states to allow international comparison among administrative national data on social protection (Eurostat, 2011). According to Esspros, social protection is defined as encompassing "all interventions from public or private bodies directed to relieve households and individuals of the burden of a defined set of risks and needs, provided that there is neither a simultaneous reciprocal nor an individual arrangement involved" (Eurostat, 2011, p. 9). Furthermore, Esspros traces the boundaries of social protection domain, making a list of the risks/needs covered, namely: sickness/health care, disability, old age, survivors, family/children, unemployment, housing and social exclusion. This means that only interventions falling within one of these areas can be labelled as social protection activity. For years 
Esspros definition has represented a yardstick in the field of data social protection statistics.

Monitoring the evolution of welfare systems implies looking at changes of several aspects of social protection. The literature on the identification and clustering of welfare regimes has proposed a number of characteristics (dimensions) to focused on (Titmuss, 1974, Esping-Andersen 1990, Ferrera et al. 2012). The type of actors delivering services, the composition of risks and needs covered, the quota of people covered and the rules for accessing benefits (e.g. whether they are means-tested or not) are among the most recurrent dimensions. However, other aspects seem particularly relevant to characterize a welfare system model, like the kind of economic transaction through which benefits are delivered: monetary transfers (benefits in cash), direct provisions of goods and services (benefits in kind) or tax breaks. Also, it is relevant to point out whether the funding of social protection is public (general government contributions from taxes) or private (social contributions from employers or from protected persons) and which is the institutional sector paying benefits.

The level of decentralization of welfare system represents a further key dimension since in some countries local governments are assigned managing and, sometimes, legislative competencies on social protection areas. To explore this issue, it is necessary to go beyond the examination of national legal systems, and take the actual implementation of constitutional provisions by decentralized entities into account (Addis et al. 2016). Effects of local social policies can be assessed only analysing sub-national data and indicators.

\section{European official statistics on social protection benefits}

Four main data sources provide internationally comparable statistics on social protection expenditures and receipts: Esspros and National Accounts (NAs)by Eurostat, Socx (Social expenditure database) by Oecd and SSI (Social Security Inquiry) by ILO.

The objective of SSI is mainly to address the lack of (comparable) social protection statistics outside the Oecd world (see ILO website). In this respect, the inquiry adopts a systematic approach compatible with existing statistical frameworks for Oecd countries. The SSI database mainly incorporates Esspros and Socx statistics when dealing with European countries social protections benefits. Esspros, in turn, is a NAs satellite account (Eurostat 2013a). Therefore, the four data sources share significant common concepts and supply statistics on common thematic areas.

National statistical offices disseminate also micro data on the supply and use of social protection services. However, these statistics seldom permit sound comparisons among countries. Data are fragmented and often inconsistent, their availability and quality vary across countries. This depends on the fact that social protection programmes are carried out by a multitude of actors (public, private or non-profit institutions) at different level of government (central, local) and a systematic and shared data gathering methodology is lacking. In the following subsections, we examine 
the main data sources for the analysis and comparison of social benefits across European countries.

\subsection{National Accounts (NAs)}

NAs record social protection expenditure under the "Social benefits category". According to the European System of Accounts (ESA 2010,Eurostat 2013a) "Social benefits are transfers to households, in cash or in kind, intended to relieve them from the financial burden of a number of risk or needs, made through collectively organized schemes, or outside such schemes by General Government (GG) units and by Non-Profit Institutions Serving Households (NPISHs); they include payments from general government to producers which individually benefit households and which are made in the context of social risks or needs" (ESA 2010,4.83). Risks or needs covered are the following: sickness, invalidity/disability, occupational accident or disease, old age, survivors, maternity, family, promotion of employment, unemployment, housing, education, general neediness (ESA 2010, 4.84). In particular, NAs distinguish two categories: "Social benefits other than social transfers in kind" and "Social transfers in kind". The first are current social transfers benefiting households (retirement pensions, unemployment allowances, family and maternity allowances, sick-leave per diem allowances) and are recorded in the Secondary distribution of income account. The second include the expenditure of GG and NPISHs on the provisions of various individual services (healthcare, education etc.) but also the reimbursement of purchases of goods and services such as medical consultations and medicines, as well as housing allowances; these transactions are recorded in the Redistribution of income account. "Social benefits other than social transfers in kind" and "Social transfers in kind" contribute to determine the amount of two significant NAs balancing items, namely "Disposable income" and "Adjusted disposable income". Disposable income equals gross primary income minus current monetary transfers paid (e.g. taxes on income and wealth or social contributions), plus monetary transfers received (among which social benefits in cash). Disposable income shows how much can be consumed without running down assets or incurring liabilities. However, it is worth reminding that Disposable income is not appropriate for comparing people's material well-being across countries with different welfare systems. In fact, depending on the type of social protection systems, a relevant share of social protection is allocated through social transfers in kind. To face this problem, The System of National Accounts 1993 (SNA 93, United Nations 1993) introduced Adjusted disposable income, which is equal to Disposable income plus social transfers in kind.

NAs allow one to distinguish various typologies of social benefits. Particularly, "Social benefits other than social transfers in kind" break down into three categories, namely "Social insurance benefits in cash", "Other social insurance benefits" and "Social assistance benefits". The first category includes benefits paid out by social security plans organized by government and by private pension plans in return 
for prior contributions (ESA 20101, 4.103). The second refers to benefits payable by employers in the contest of other employment social insurance schemes (ESA $20101,4.104)$. The third category identifies benefits provided without any previous contribution of beneficiaries (ESA 2010 4.105). Within "social transfers in kind", NAs distinguish individual goods and services provided directly to the beneficiaries by non-market producers (i.e. by GG or NPISHs) from individual goods and services provided directly by market produces on behalf of GG or NPISHs (ESA 2010, 4.109).

NAs classify the different kinds of social benefits according to the different types of paying sectors, i.e. by institutional sectors and by the sub-sectors thereof (e.g. Private/Public within Non-financial corporations or Central/Local governments within General Government).

Finally, NAs supply two pieces of information concerning decentralization and territorial data. The former concerns social benefits (namely "Social benefits other than social transfers in kind" and "Social transfers in kind provided by market producers") paid by Local government; the latter is the distribution of "Social benefits other than social transfers in kind" received by Households $(\mathrm{HH})$, by regions (Nuts 2).

\subsection{The European System of Integrated Social Protection Statistics (Esspros)}

Esspros records the accounting of social protection schemes distinguishing receipts (sources of financing) from expenditures (uses of financing). Two supplementary modules contain statistical information on pensions' beneficiaries and on net social benefits (Eurostat,2016).

Receipts are analysed according to the nature of the payment (general government contributions,employers' social contributions and contributions paid by protected people) as well as to the kind of paying institutional sector. Institutional sectors correspond exactly to the NAs' ones. Expenditures include social benefits but also administration costs (costs charged to the scheme for its management and administration) and other miscellaneous costs.

Social benefits are further analysed by function and by type. The function identifies the primary purpose for which social protection is provided (Eurostat 2011, 109), i.e. the risk or need covered. The type of benefit refers to the form in which the protection is provided. In particular, Esspros distinguishes between benefits paid in cash (further detailing between those paid at regular intervals or in the form of a lump sum) and benefits in kind (Eurostat 2011, 110-115). Finally, Social benefits are broken down between means-tested and non means-tested benefits. Means-tested benefits are conditional on the beneficiary's income and/or wealth falling below a specified level (Eurostat, 2011, 116, 117). 
Esspros database does not contain details at the local level. However,it allows one to detect the part of social protection receipts coming from "State and local government".

\subsection{Social expenditure database (Socx)}

The Oecd database was developed in the 1990s as a tool for monitoring trends in aggregate social expenditure and analysing changes in its composition. Oecd defines social expenditures as "the provision by public and private institutions of benefits to, and financial contributions targeted at, households and individuals in order to provide support during circumstances which adversely affect their welfare, provided that the provision of the benefits and financial contributions constitutes neither a direct payment for a particular good or service nor an individual contract or transfer"(Adema et al., 2011, p. 90).

Oecd distinguishes nine social different policy areas, which only approximately correspond to the risks/needs specified by NAs and Esspros: Old age, Survivors, Incapacity-related benefits, Health, family, Active labour market programmes, Unemployment, Housing, and Other social policy areas. Social expenditure comprises cash benefits, direct in-kind provision of goods and services (benefits in kind), and tax breaks with social purposes.

Social benefits are classified as public when general government (central, state or local governments, social security funds) controls the relevant financial flows. All social benefits not provided by general government are considered private. Private social benefits further break down into two sub-categories: mandatory private social expenditure, which includes social support stipulated by legislation but operated through the private sector (e.g. direct sickness benefits paid by employers); voluntary private social expenditure, which includes benefits accruing from privately operated programmes. Socx mainly incorporates Esspros data when dealing with European countries, with the exception of health and active labour market programmes data, which come from thematic Oecd databases.

Oecd publishes also an estimate of net social expenditure, which consider the effects of tax systems on social protection. Broadly speaking, this happens through direct taxation of benefit income, indirect taxation of consumption by benefit recipients and tax breaks for social purposes (Adema et al. 2011). This effect can be considerable and vary across countries.

\subsection{EU statistics on income and living conditions (Eusilc)}

Eusilc is the reference source for comparative statistics on income distribution and social inclusion in the European Union. The reference population includes all private households and their current members residing in the territory of the countries 
at the time of data collection. Eusilc collects information on social benefits received by households and their members. Social benefits are defined (in accordance with Esspros) as "current transfers received during the income reference period by households intended to relieve them from the financial burden of a number of risk or needs, made through collectively organised schemes, or outside such schemes by government units and NPISHs". Areas covered are the following: unemployment benefits, old-age benefits, survivor benefits, sickness benefits, disability benefits, and education related allowances. Eusilc benefits do not cover benefits in kind, with the only exception of housing benefits. Finally, Eurostat does not deliver estimates of benefits by function based on Eusilc data, neither at the national nor at the subnational level.

\section{Combining information from different data sources}

Differences among data sources are due to two main reasons. The first reason concerns the different boundaries of the social domain, i.e. the distinction between social spending and not-social spending. The second relates to the breakdown of social expenditure among functions. NAs and Esspros have undoubtedly a more homogeneous base and comparable data although some differences are present. A major difference is that NAs include Education in the social domain while Esspros does not. Furthermore, social benefits within Esspros cover both current and capital transfers whereas the definition offered by NAs refers to current transfers only. Finally, NAs in kind transfers also cover transfers, which do not have a social protection objective. For example, they include expenditures on sport, cultural and recreational activities (Eurostat 2011, p. 65). Esspros statistics undoubtedly provide a richer analysis of social protection accounting than NAs. However, NAs have the advantage of directly linking changes in social protection expenditure to changes in households disposable income. The scope of Socx is arguably larger than that of NAs and Esspros. The first point is that Socxs expenditure also includes lost revenues due to tax breaks with social purposes (Adema et al. 2011, p. 110). Furthermore, differently from NAs and Esspros, Socx includes all spending on public health expenditures or labour market programmes like investment in medical facilities, preventive health initiatives or health education and training, not only expenditures that can be "allocated" to individuals or families (individual consumptions). Like Esspros and differently from NAs, Socx does not include education within the social domain (except pre-primary education, which is recorded under the family policy area). All Esspros social protection benefits are included in Socx with the only exception of some expenditures for disability, sickness and unemployment that are directly taken from thematic Oecd databases.

Table 1 attempts to give an overview of available information on social protection benefits at the macro and micro level (limited to Eusilc). 


\begin{tabular}{|c|c|c|c|c|}
\hline Social benefits paid or received & NAs & Esspros & Socx & Eusilc \\
\hline By Needs/risk covered & paid & paid & paid & received \\
\hline Means-tested/ Non-means tested & & paid & & \\
\hline Cash/in-kind & paid & paid & & \\
\hline Public/private & & & paid & \\
\hline Gross/net & & paid & paid & \\
\hline By paying sector & received & received & & \\
\hline By geographic area & received & & & received \\
\hline By households' typologies & & & & received \\
\hline
\end{tabular}

Table 1 Social benefits (paid or received) in EU official statistics.

The first column makes a list of main social benefits categorizations, which can be detected in at least one of the analysed data sources. The following columns are headed to the data sources described in Section 3.
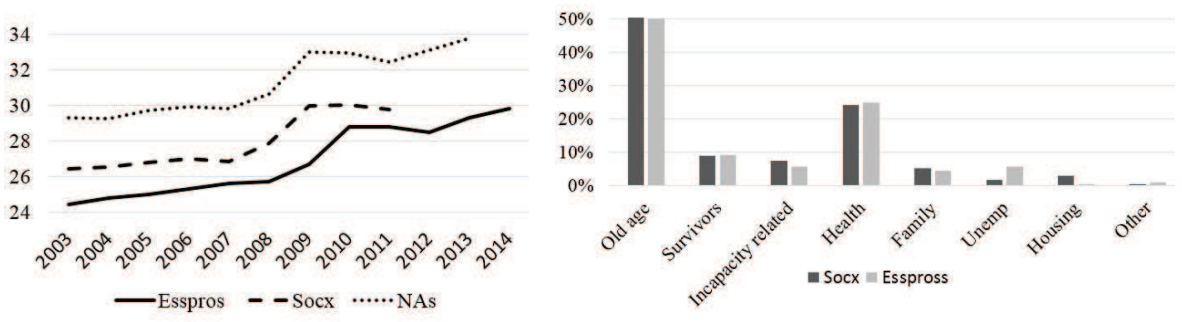

Fig. 1 Gross social protection expenditure (\% GDP) and Social benefits by function (shares),left and right panel, respectively - Socx Esspros and NAs data - Italy 2011.

Full cells indicate that the data source (column heading) contains the information described in the row heading. Furthermore, the cell specifies whether social benefits are recorded as received or paid transfers. We observe that, in some cases, more than one data source gives the same kind of information. In the following, we present some analysis on overlapped topics for Italy. Fig. 1, left panel, shows gross social protection expenditure in percentage of GDP from 2003 to 2014, computed on the basis of NAs, Esspros or Socx data. NAs percentages are higher than Socx percentages, which in turn overcome Esspros values. Net social expenditure shows similar levels in Espross and Socx databases, about 25-26 percentage points of GDP according to the latest estimates. Fig.1 (right panel) compares Esspros and Socx data on gross expenditures by type of risk/need covered.

Fig.2 compares cash benefits (left panel)and benefits in kind (right panel) both expressed as percentages of GDP, stemming from Esspros, Socx and NAs data 

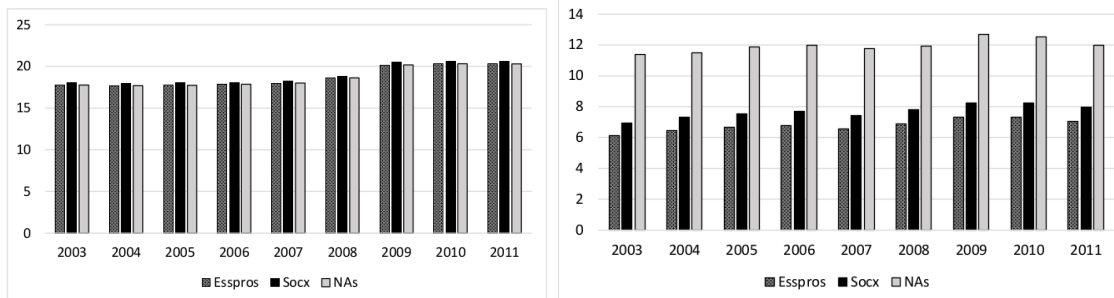

Fig. 2 Cash benefits, and Benefits in kind (\% GDP), left and right panel, respectively - Socx Esspross and NAs data - Italy, years 2003-2011.

sources. Percentages show some significant differences, however changes in time show similar patterns.

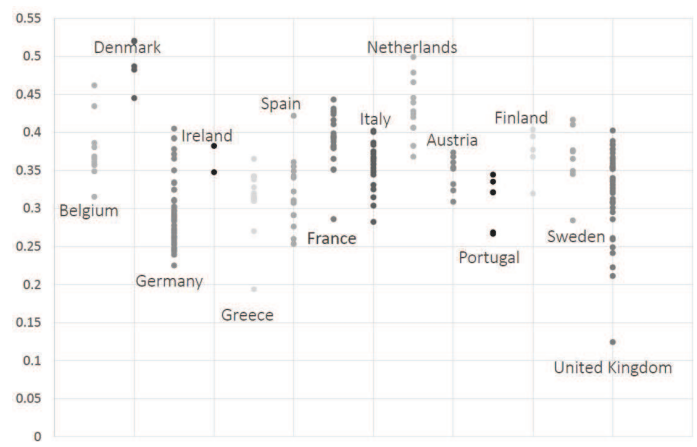

Fig. 3 Share of Households disposable income covered by cash benefits by regions (Nuts 2), in a selection of European countries - NAs data, year 2013.

Our exploring of available official statistics on social benefits has shown a general shortage of data for measuring the level of decentralization of a welfare system. Fig. 3 shows disparities among a selection of European countries, based on the only indicator available, namely the amount of cash benefits received by households, by region (see Section 3.1). In particular, the figure shows the share of disposable income covered by cash benefits in each region (dot) of each country.

National statistical offices disseminate statistics on local social protection activity. Istat, for example, regularly carries out a survey on municipal social protection expenditure, which gives an interesting insight into the heterogeneity of social expenditure distribution on the Italian territory. Fig. 4 shows how municipalities of each region share differently their resources among family, old age and disability functions. From an in depth analysis, which is not the focus of the present paper and it is not reported here due to space constraints, we can state that disparities in social protection provision generally do not agree with the local population needs and the specific demographic dynamics (see, for example, Venturi, 2017). 


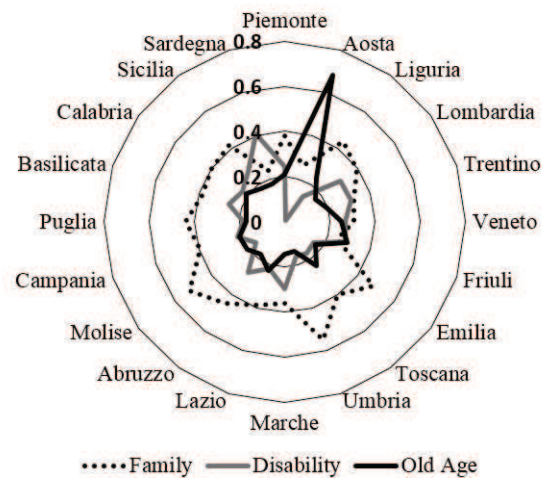

Fig. 4 Municipal social expenditure by function and region (Nuts2) - Italy, 2012.

\section{Concluding remarks}

The main objective of this study was to map comparable official statistics on social protection benefits at national and local levels for European countries. To this end, we explored Eurostat and Oecd main data sources on social protection accounting to provide a complete picture of data and indicators theoretically available, pointing out differences and matches among the different data sources. According to our analysis, European welfare states can be compared only at the country level and not at the local level, at least for what concerns the financial aspects. The distribution of cash benefits by region (Nuts 2) from National Accounts, represents the only official data on social protection benefits delivered at the local level. Furthermore, currently disseminated Eusilc micro data allow one to estimate cash benefits only for large geographical areas (Nuts 1). National statistical offices supply more information on social protection at the local level. Istat for example disseminates data and indicators on municipal social protection expenditures at the province level. The analysis shown in Section 4 shows significant territorial disparities. Further research is required to understand whether they are the successful responsiveness of local governments to the specific needs of local populations, or, conversely, a sign of inequity and territorial injustice.

\section{References}

1. Adema, W., P. Fron and M. Ladaique (2011), Is the European Welfare State Really More Expensive?: Indicators on Social Spending, 1980-2012; and a Manual to the Oecd Social Expenditure Database (Socx), Oecd Social, Employment and Migration Working Papers, No. 124, Oecd Publishing. http://dx.doi.org/10.1787/5kg2d2d4pbf0-en

2. Addis, P., Coli, A., Pacini, B. (2016). Welfare State and Local Government: the Impact of Decentralization on Well-being. 34th IARIW General Conference, Dresden, Germany. August 
21-27, 2016 .

3. Bonnet, F. and L. Tessier (2013). Mapping international social protection statistics and indicators. ESS Paper Series (SECSOC) - ESS 38- ILO.

4. Esping-Andersen G. (1990) The three worlds of welfare capitalism, Cambridge, Polity Press.

5. Eurostat (2011). The European System of European System of Integrated Social Protection Statistics. Manual.

6. Eurostat (2013a). European System of Accounts (ESA 2010). Manual.

7. Eurostat (2013b). NUTS Nomenclature of Territorial Units for Statistics, by regional level.

8. Eurostat (2016). Statistics Explained (http://epp.eurostat.ec.europa.eu/statisticsexplained/).

9. Felici, M., Tassa, E. (2010). Politiche sociali e livelli di governo. Riv. dir. fin., fasc.3 .

10. Ferrera, M., Fargion, V., Jessoula, M. (2012). Alle radici del Welfare all'italiana Origini e futuro di un modello sociale squilibrato. Saggi e ricerche, collana storica della banca dItalia. Marsilio.

11. Saltman Richard B. (2006). Decentralization, re-centralizazion and future European health policy, European Journal of Public Health, Vol. 18, No 2, 104-106

12. Titmuss R. (1974) Social policy. An introduction, London, Allen\&Unwin.

13. United Nations (1993) System of National Accounts 1993. Manual.

14. Venturi S. (2017). Disparities in Local Social Protection Systems from a Demographic Perspective. The Population Ageing. In: Policy, Welfare and Financial Resources: The Impact of Crisis on Territories, Pisa University Press. 